\title{
研究論文
}

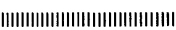

\section{食塩水溶液中に括ける $\mathrm{Al}-\mathrm{Si}$ 合金の \\ 腐食挙動に及ぼすけい素の効果*}

世利 修美**.田頭 孝介**

\author{
Effect of silicon in Al-Si alloys on \\ corrosion behavior in $\mathrm{NaCl}$ solution*
}

Osami SERI** and Kohsuke TAGASHIRA**

\begin{abstract}
The effect of silicon on corrosion behavior of Al-Si alloys has been investigated by means of immersion corrosion test and electrochemical mesurements. The corrosion weight loss increased with increasing silicon content in Al-Si alloys. Corrosion of $\mathrm{Al}-\mathrm{Si}$ alloys in aerated $0.1 \mathrm{M} \mathrm{NaCl}$ solution has been controlled by the cathodic process of water reduction which reacts on the eutectic silicon which is segregated.
\end{abstract}

Keywords: corrosion, Al-Si alloys, cathodic control, eutectic silicon, water reduction

(Received June 23, 1986)

\section{1. 緒言}

アルミニウム材料に拈いてけい素は重要な合金元素の 一つである。アルミニウム腐食に及ぼすけい素の影響に ついての研究はすでに数多くなされているが1),2),31，そ の影響を $\mathrm{Al}-\mathrm{Si}$ 合金の実際に起つた腐食に当てはめ子細 に検討するとさらに追求する項目は多いように思われ る。

既報4)に括いて, $\mathrm{Al}-\mathrm{Si}$ 合金中のけい素添加量の増加 $(0.01 \sim 1.49 \% \mathrm{Si})$ に応じて $\mathrm{Al}-\mathrm{Si}$ 合金の腐食量は増加す る結果を得たが，そのけい素添加量の増加に応じてア， ード，カソード分極曲線に差異は生じなかつた。

本報では，この直接測定法の結果としての腐食量と間 接測定法の結果としての分極曲線との間の齟龉の究明を 試み, $\mathrm{Al}-\mathrm{Si}$ 合金の基礎データとして興味ある知見を得 たのでここに報告する。

\section{2. 実験方法}

\section{1 供試材}

$\mathrm{Al}-\mathrm{Si}$ 合金の化学分析值を Table 1 に示す。

試片の作製は高純度アルミニウム $(99.97 \% \mathrm{Al})$ にけ い素を添加し, 溶解, 鋳造後, 均質化処理 $\left(540^{\circ} \mathrm{C}\right.$ で
160時間保持，後炉冷）を経て，熱間および冷間圧延を 行い, 厚さ $1 \mathrm{~mm}$ の板とした。腐食減量の時の試料表面 積は $5 \times 6 \mathrm{~cm}$ ，分極曲線のそれは $1.5 \times 1.5 \mathrm{~cm}$ とした。

各試片の前処理はアルカリ洗浄 $\left(70^{\circ} \mathrm{C} の 10 \% \mathrm{NaOH}\right.$ 水溶液で 1 分間浸漬）を行い，水洗後，中和処理（室温 の $30 \% \mathrm{HNO}_{3}$ 水溶液で 1 分間浸漬）を施し, 十分な水 洗，乾燥の後，測定に供した。

電気抵抗測定用の試料は線引加工によつて $0.6 \mathrm{~mm} \phi$ の線材を制作し, 加工歪除去後 $\left(560^{\circ} \mathrm{C}\right.$ で約 30 分間窒素 ガス雾囲気で焼鈍）測定に供した。

実験終了後, 試料表面に付着した腐食生成物は脱膜処 理*を行い溶解除去した。

Table 1 Chemical composition of Al-Si alloys $(\mathrm{wt} \%)$

\begin{tabular}{c|c|c|c|c}
\hline \hline \multirow{2}{*}{$\begin{array}{c}\text { Specimen } \\
\text { No. }\end{array}$} & \multicolumn{3}{|c|}{ Composition } & \multirow{2}{*}{ History } \\
\cline { 2 - 4 } & $\mathrm{Si}$ & $\mathrm{Fe}$ & $\mathrm{Al}$ & \\
\hline $\mathrm{S} 1$ & 0.10 & 0.01 & $\mathrm{bal}$ & \\
$\mathrm{S} 2$ & 0.50 & 0.02 & $\mathrm{bal}$. & \\
$\mathrm{S} 3$ & 0.97 & 0.03 & $\mathrm{bal}$ & rolled \\
$\mathrm{S} 4$ & 1.49 & 0.02 & $\mathrm{bal}$ & \\
\hline
\end{tabular}

* 軽金属学会春期大会講演（61-5）にて一部発表。

** 室蘭工業大学第 2 部機械工学科 (室蘭市)。Muroran Institute of Technology (Muroran). 


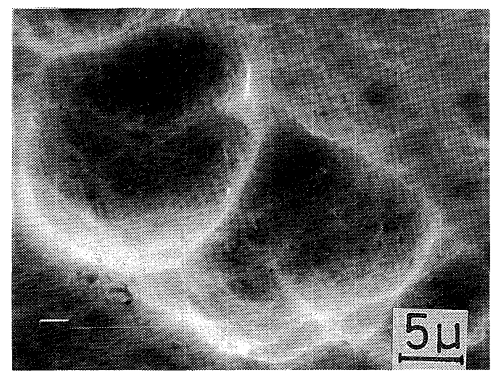

(a) $\mathrm{S1}$

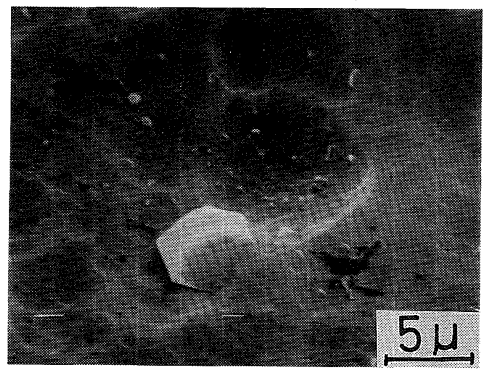

(c) $\mathrm{S3}$

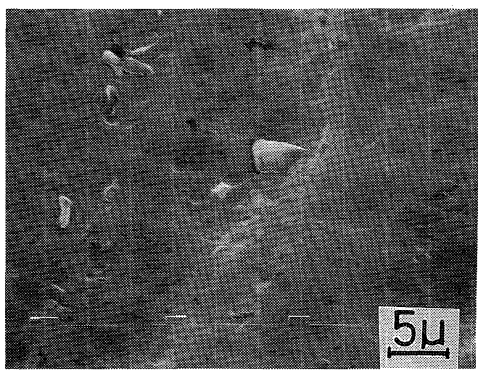

(b) $\mathrm{S} 2$

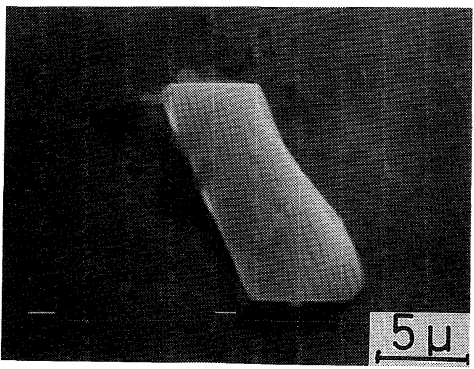

(d) 54

Fig. 1(a) (b) SEM observation of surface on Al-Si alloys (specimen No. S1 $\sim \mathrm{S} 4$ ) before immersion test.

\section{2 試験液}

試薬は特級を用いた。イオン交換水の容量はすべて $1 l$ にし，所定の濃度で実験に供した。

溶存酸素の導入方法としては, 溶液擋找状態でガラス ボールフィルタを通して空気（エヤポンプで約 0.41 ) min）を吹込み, 通気状態にしておいた。溶存酸素の除 去方法については上記と同様な機構で，空気を窒素ガス $\left(99.99 \% \mathrm{~N}_{2}\right.$ を約 $\left.0.4 \mathrm{l} / \mathrm{min}\right)$ に取り替えて吹込み, 脱気 状態にしておいた。

\section{3 測定方法}

電気化学的測定方法の一つの分極曲線測定法について は, 通常のポテンシオスタットを用いた動電位法で行つ た。その時の電位掃引速度は $0.4 \mathrm{mV} / \mathrm{sec}$ としたアノ 一ド分極曲線測定では，まずカソード側 $(-5 \mathrm{~mA} / 2.25$ $\mathrm{cm}^{2}$ ) で10分間保持後，アノード分極曲線を描かせた。 照合電極はすべて飽和塩化カリウム水溶液中の $\mathrm{Ag} /$ $\mathrm{AgCl}$ 電極を使用した。分極曲線への $\mathrm{iR}$ 補正は省略し

* 腐食生成物除去処理の一方法であり，本研究ではク ロム酸ナトリウム $4 \%$, リン酸 $10 \%$ 残り純水の溶液 中で $80^{\circ} \mathrm{C} ， 4$ 分間浸漬による方法を採用した。
た。

電気抵抗測定については, 液体窒素を満たしたデュワ 一瓶中に試料を浸漬し, 通常の 4 端子法5)で行つた。

\section{3. 実験 結果}

\section{$3.1 \mathrm{Al}-\mathrm{Si}$ 合金の金属組織観察}

腐食実験を行う前に，本実験で用いた試料番号 $\mathrm{S} 1$ 〜 S4 の表面の金属組織を調べるため SEM 観察を行つた。 それらの写真をそれぞれ Fig. 1(a)〜 (d) に示す。

けい素添加量を $0.10 \%$ から $1.49 \%$ (試料番号 $\mathrm{S} 1$ ～S4) まで変えているが，その影響は表面に露呈している晶出 けい素**の大きさに現れている。つまり，試料番号 S4 の表面では $5 \sim 10 \mu$, 試料番号 S3 では $7 \sim 8 \mu$, 試料番 号 S2 では 2 3 $3 \mu$ の長方形や三角形の晶出けい素が見ら れる。また, 試料番号 $\mathrm{S} 2 \sim \mathrm{S} 4$ にかけては $1 \mu$ 以下の小

** $\mathrm{Al}-\mathrm{Si}$ 平衡状態図から本試片中のけい素の存在形 態をけい素添加量だけで判断すると固溶けい素と 析出けい素の 2 種類となる。しかし，4.1で述べ るように，実際の試片表面を子細に調べると晶出 けい素の存在が観察されている。これはけい素の 偏析に起因するものと考えられる。 


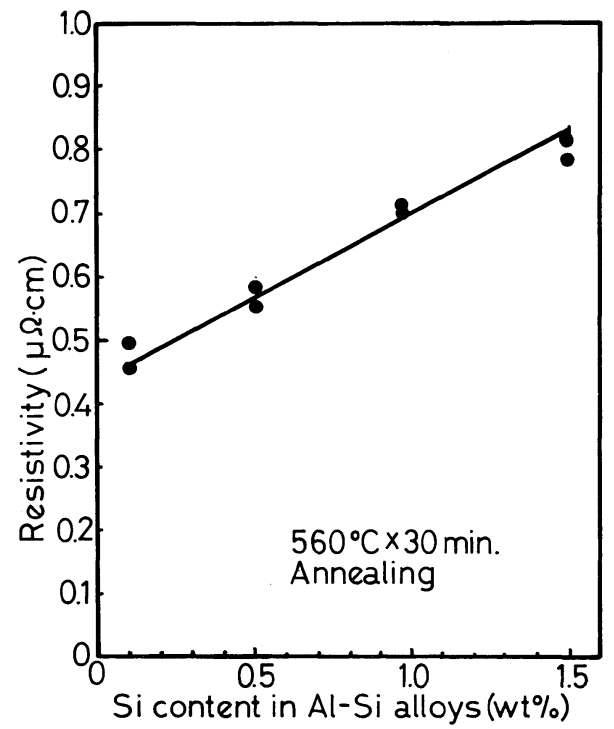

Fig. 2 Resistivity of Al-Si alloys plotted as a function of silicon content.

さなけい素も観察されている。試料番号 S1については 晶出けい素などの 2 次相は観察されなかつた。

アルミニウム母地は試料番号 S1〜S4 のすべてにわた つて静止海面のような表面をしている。

\section{$3.2 \mathrm{Al}-\mathrm{Si}$ 合金中のけい素の固溶度}

$\mathrm{Al}-\mathrm{Si}$ 合金中のけい素の存在状態は析出けい素や3.1で 観察された晶出けい素の他にアルミニウム母地中に固溶 されている固溶けい素がある。この固溶けい素の多寡は 電気抵抗測定值の大小に反映される。

そこで本実験で用いた試料の比抵抗を測定し，固溶け い素の量を見積つた。それらの結果を Fig. 2 に示す。

比抵抗值は直線的に増加しており, 本実験で使用した $\mathrm{Al}-\mathrm{Si}$ 合金試料の比抵抗值とそれらの添加けい素量との 間の相関関係は有意水準 $5 \%$ で有意である。その回帰式 は次式となる。

$$
\rho=0.46+0.24[\mathrm{Si}]
$$

ただし, $\rho: \mathrm{Al}-\mathrm{Si}$ 合金の比抵抗值 $(\mu \Omega \cdot \mathrm{cm})$

[Si] : Al-Si 合金中のけい素添加量 (wt\%)

\section{3 腐食減量}

試料番号 $\mathrm{S} 1 \sim \mathrm{S} 4$ を空気吹込 久, 溶液擋找状態下の $0.1 \mathrm{MNaCl}$ 水溶液中で 1,000 時間浸漬した後の腐食減量 をFig. 3 亿示す。腐食減量と $\mathrm{Al}-\mathrm{Si}$ 合金中のけい素添 加量間の関係は有意水準 $5 \%$ で相関関係がある。その回 帰式は次式となり, 腐食減量は $\mathrm{Al}-\mathrm{Si}$ 合金中のけい素添 加量が増加するに従い直線的に増加する。

$$
\Delta W=10.6+40.9[\mathrm{Si}]
$$

ただし， $\Delta W: \mathrm{Al}-\mathrm{Si}$ 合金の腐食減量 $\left(\mathrm{mg} / 60 \mathrm{~cm}^{2} / 10^{3}\right.$

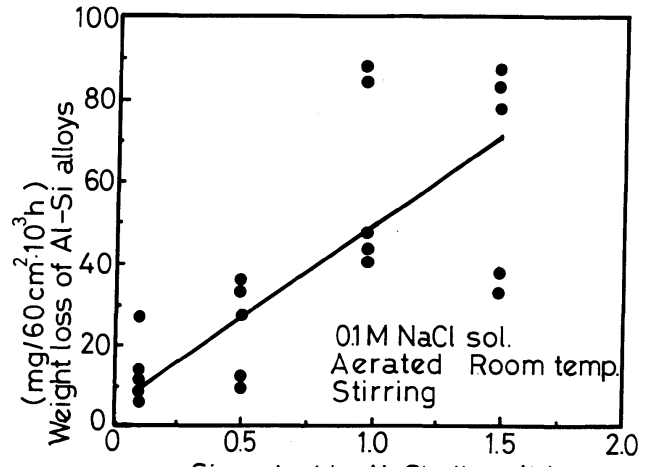

Si content in Al-Si alloys (\%)

Fig. 3 Weight loss of Al-Si alloys in aerated $0.1 \mathrm{M}$ $\mathrm{NaCl}$ solution.

h)

$[\mathrm{Si}]: \mathrm{Al}-\mathrm{Si}$ 合金中のけい素添加量 $(\mathrm{wt} \%)$ 実験終了後の試料の表面状態の SEM 観察写真を Fig. 4(a) 〜 (d) 亿示す。試料番号 S1，S2 では晶出けい 素などの 2 次相は注とんぞ観察されていない。試料番号 S3, S4 では Fig. 1 の実験前の表面観察と同じょうな角 の鋭い長方形や六角形の晶出けい素や小さなけい素が観 察されている。これら 2 次相の残存は晶出けい素や析出 けい素は腐食過程において溶解しなかつたことを意味す る。

アルミニウム母地は試料番号 $\mathrm{S} 1 \sim \mathrm{S} 4$ 共腐食実験前之 比べて肌荒れの様相を呈している。腐食前後の表面状態 そおいて最も特徵的なことは析出けい素周囲の窪地の有 無である。つまり，腐食前存在していなかつたけい素周 囲の寉地は腐食後必ず存在していることである。試料番 号 S3, S4 の表面に存在している $10 \mu$ 前後の晶出けい素 の周囲には必ず窪地が観察されている。この窪地は食孔 ではない***そのの宔地内の底や側面はなめらかな表面 状態を保つており, Fig. 4(c) では脱落寸前の晶出けい素 が観察されている。

肉眼観察では压延方向に腐食は生成して抢り，その傾 向は試料番号 S3, S4 に沶いて著しかつた。

\section{4 腐食電位の経時変化}

溶液擋拌, 空気吹込みの $0.1 \mathrm{MNaCl}$ 水溶液中での試 料番号 S1〜S4 の腐食電位の経時変化を Fig. 5 亿示す。 浸漬12１3時間後にお斿る腐食電位はー0.84〜 $-0.94 \mathrm{~V}$ の卑な電位域に移行している。その後 $-0.64 \sim-0.70 \mathrm{~V}$ の間を200時間位変動し, 再び卑貴方向の推移を繰り返 している。

*** 食孔の定義は深さ/直径の比が 4 6 以上である。 Fig. 4(c)やFig. 4(d)から, 析出けい素周囲の窪 地のそれは0.2〜1 位である。 


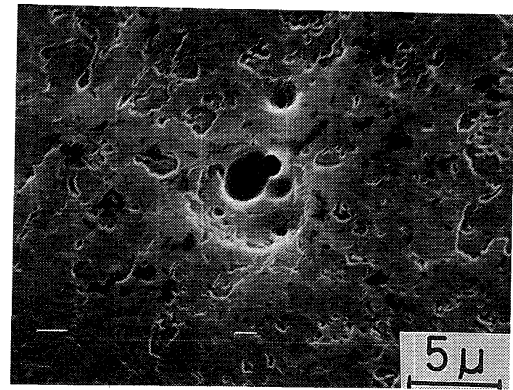

(a) $\mathrm{S} 1$

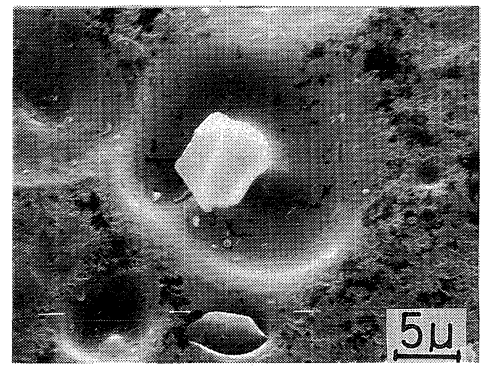

(c) $\mathrm{S3}$

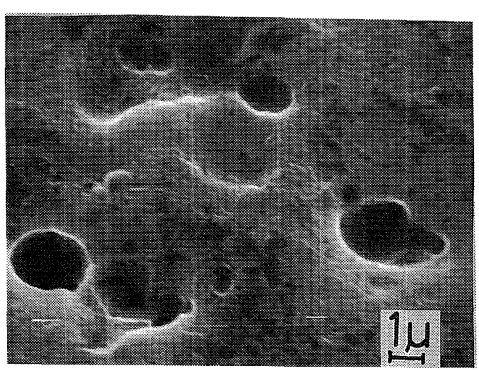

(b) $\mathrm{S2}$

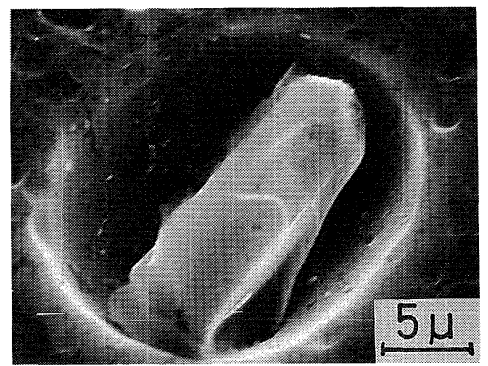

(d) $\mathrm{S} 4$

Fig. 4(a) $\sim$ (d) SEM observation of surface on Al-Si alloys (specimen No. S1 $\sim$ S4) after immersion test.

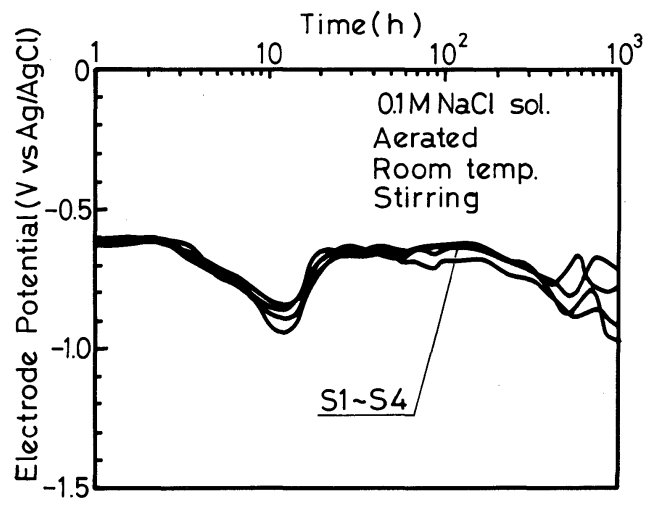

Fig. 5 Corrosion potential vs time curves for $\mathrm{Al}-\mathrm{Si}$ alloys (specimen No. S1 S4) in aerated $0.1 \mathrm{M}$ $\mathrm{NaCl}$ solution.

アノード分極曲線測定結果 ${ }^{4}$ から, 孔食電位 $\left(E_{\mathrm{pit}}\right)$ はー $0.6 \mathrm{~V}$ である。腐食電位 $\left(E_{\text {corr }}\right)$ との関係より,

$$
E_{\text {corr }}<E_{\text {pit }}
$$

となり，孔食は生じないことになる。Fig. 4(a)〜 (d)の SEM 観察から, 方位ピットは存在せず, この電気化学

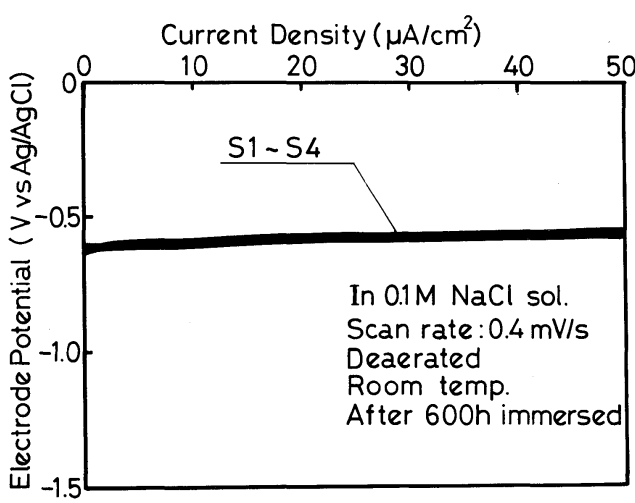

Fig. 6 Anodic polarization curves for Al-Si alloys (specimen No. $\mathrm{S} 1 \sim \mathrm{S} 4$ ) in $0.1 \mathrm{M} \mathrm{NaCl}$ solution after $600 \mathrm{~h}$ immersion period.

的推論は支持されている。

数回の腐食電位の測定結果から, 試料番号 $\mathrm{S} 1 \sim \mathrm{S} 4$ 中 のけい素添加量とそれらの腐食電位の間には一義的な対 応は認め難い。しかし，一般的な傾向として浸漬500時 間以降の試料番号 $\mathrm{S} 1, \mathrm{~S} 2$ の腐食電位は試料番号 S3, S4 


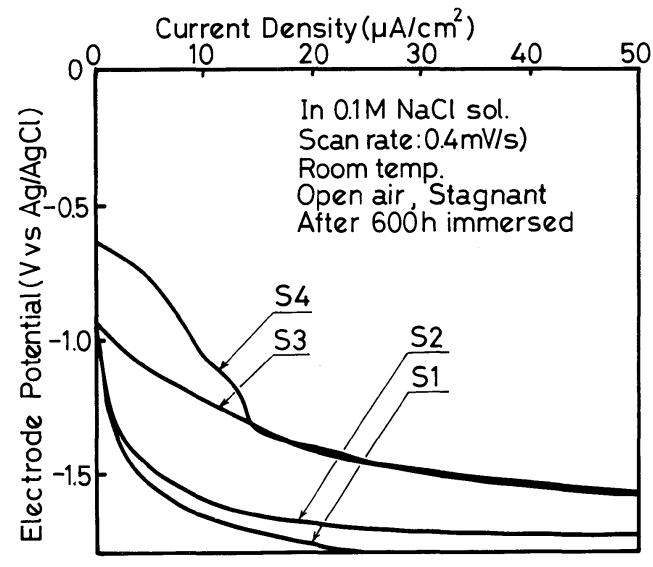

Fig. 7 Cathodic polarization curves for $\mathrm{Al}-\mathrm{Si}$ alloys (specimen No. $\mathrm{S} 1 \sim \mathrm{S} 4$ ) in $0.1 \mathrm{M} \mathrm{NaCl}$ solution after $600 \mathrm{~h}$ immersion period.

のそれらより約 $0.1 \mathrm{~V}$ 卑な電位域で変動していた。

\section{5 分極曲線の経時変化}

通常の腐食過程ではアノード溶解による表面形状変化 やカソード反応による溶液環境変化が起こることが予想 される。そこで3.4の腐食電位測定において腐食電位の 差が比較的大きく表れている浸漬600時間後のアノード, カソード分極曲線を測定した。その結果をFig. 6,

Fig. 7 に示す。

Fig. 6 より, 試料番号 $\mathrm{S} 1 \sim \mathrm{S} 4$ の孔食電位は $-0.6 \mathrm{~V}$ で浸漬直後のアノード分極曲線と同じ形をしており4), アノード分極曲線の経時変化はほとんど認められない。

Fig. 7 と浸漬直後のカソード分極曲線 ${ }^{4}$ を比較すると, 経時変化が起こつている。つまり, 浸漬直後のカソード 分極曲線は試料番号 $\mathrm{S} 1 \sim \mathrm{S} 4$ にがけほとんど差異は認 められなかつたが浸漬600時間のカソード分極は小さく なり, 経時変化を起こしている。その程度は試料番号 $\mathrm{S} 1, \mathrm{~S} 2$ よりも試料番号 S3, S4 の方が大きい。

溶存酸素の還元限界電流值を示す『垂直部分』は現れ

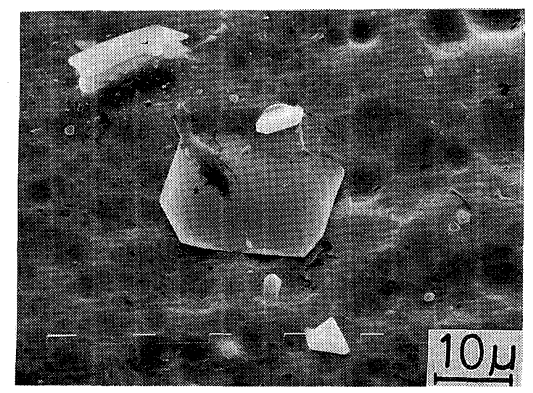

ないこと，溶液撹拌でもカソード電流は振動しないこと から，このカソード分極曲線に対応するカソード反応は 水の還元反応である。

\section{6 アノード定電流保持後の表面観察}

3.3 の晶出けい素周井の窪地は腐食溶解した場所であ るが， 3.5 の試料番号 $\mathrm{S} 1 \sim \mathrm{S} 4$ のアノード分極曲線の測 定結果からはけい素添加量の多寡に対応した差異は認め られず，また，アノード溶解の起点などの場所に関する 情報は得られない。そこでアノード溶解が起こりやすい 場所, つまり皮膜の弱い場所は晶出けい素周囲の窪地か どうか判別するためアノード定電流を強制的に流しその 表面状態を観察した。試料番号 S4 を代表に取つて，1 $\mu \mathrm{A} / \mathrm{cm}^{2 * * * *}$ で43時間流した時の表面 SEM 写真を Fig. 8 に示す。

表面には 5 $20 \mu$ 位の晶出けい素が観察されている が，その周囲に窪地は見られない。実験前の表面状態と 同様にアルミニゥム母地は滑らかである。アノード溶解 が起こりやすい場所は晶出けい素周囲の窪地だけとは限 らないことを示している。

この事実は 3.3 の窪地の成因はアルミニウム母地の表 面皮膜の強弱という材料側だけでなく, 晶出けい素が存 在すること自体によつて起こる環境変化をも考慮しなけ ればならないことを示唆している。

\section{7 定電位保持のカソード電流の変化}

3.2 より, 試料番号 $\mathrm{S} 1 \sim \mathrm{S} 4$ とけい素添加量が増えるに つれて固溶けい素は増加する。特に, 試料番号 S3, S4 は固溶けい素, 析出けい素, 晶出けい素の 3 種類が共存 している。また， 3.5 のカソード分極曲線の経時変化に おいて, けい素添加量の多い試料番号 S3, S4のカソー ド分極は小さくなる結果を得た。そこで $\mathrm{Al}-\mathrm{Si}$ 合金のカ

\footnotetext{
*****試料番号 $\mathrm{S} 1 \sim \mathrm{S} 4$ の腐食量の值は $10 \sim 90 \mathrm{mg} / 60$ $\mathrm{cm}^{2} / 10^{3} \mathrm{~h}$ である。この腐食速度を全面腐食速 度に換算すると約 $1 \sim 5 \mu \mathrm{A} / \mathrm{cm}^{2}$ になる。ここで はアノード分極曲線の電流值などを勘案して $1 \mu \mathrm{A} / \mathrm{cm}^{2}$ とした。
}

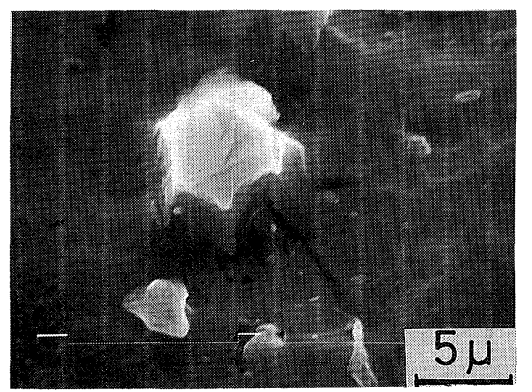

Fig. 8 SEM observation of surface on Al-Si alloys (specimen No. S4) after galvanostatic dissolution $\left(1 \mu \mathrm{A} / \mathrm{cm}^{2} \times\right.$ $43 \mathrm{~h})$ test. 


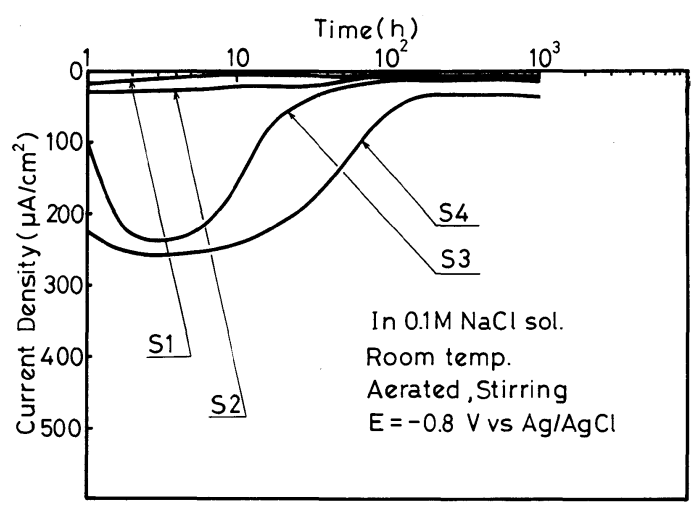

Fig. 9 Change of cathodic current density for $\mathrm{Al}-\mathrm{Si}$ alloys (specimen No. S1 S4) in $0.1 \mathrm{M} \mathrm{NaCl}$ solution.

ソード反応の特徵を調べるため, 定電位保持のカソード 電流の変化を調べた。 3.4 の腐食電位の測定からカソー ド反応域を $-0.8 \mathrm{~V}$ にり, 空気吹込み，溶液擋拌状態 ・下のカソード電流の変化を調べた。その結果を Fig. 9 に示す。

試料番号 $\mathrm{S} 1, \mathrm{~S} 2$ はー $20 \mu \mathrm{A} / \mathrm{cm}^{2}$ 以下のカソード電流 が流れている。試料番号 S3, S4 では 2 4 時間に -250 $\mu \mathrm{A} / \mathrm{cm}^{2}$ 前後の極大值を示す。明らかに試料番号 $\mathrm{S} 3, \mathrm{~S} 4$ は試料番号 $\mathrm{S} 1, \mathrm{~S} 2$ と違つたカソード電流の経緯曲線を 示している。100時間以降では, 試料番号 S3 は約 -30 $\mu \mathrm{A} / \mathrm{cm}^{2}$, 試料番号 $\mathrm{S} 4$ ではー $40 \mu \mathrm{A} / \mathrm{cm}^{2}$ のカソード電流 が流れている。この事実は試料番号 S3, S4の表面には 試料番号 $\mathrm{S} 1, \mathrm{~S} 2$ よりもカソード反応が起こりやすい物 質が存在していることを示している。

\section{4. 考 察}

\section{$4.1 \mathrm{Al}-\mathrm{Si}$ 合金の金属組織}

本実験で用いた Al-Si 合金試験片の金属組織を考察す る。

$\mathrm{Al}-\mathrm{Si}$ 平衡状態図は典型的な共晶組織であり, $\alpha$ 固溶 体の最大けい素固溶量は $577^{\circ} \mathrm{C} て ゙ 1.65 \%$ であ。従つて, 本実験で用いた Al-Si 合金試片中のけい素は Table 1 の 添加量の範囲から判断すると, $\alpha$ 固溶体中に固溶されて いる固溶けい素とそれから析出してできた析出けい素の 2 種類だけが出現しているはずである。しかし，Fig. 1 (c) や (d) で観察された $10 \mu$ 前後の析出物は $\alpha$ 固溶体か らの析出物とは考え難く, 偏析によつて生成された晶出 けい素と考えられる。この析出物の形状は長方形や六角 形を示していることも考慮すると, 偏析が起こつた可能 性が強いと考えられる6)。

この晶出けい素は $\mathrm{Al}-\mathrm{Si}$ 合金中のけい素の添加量が多 ければ多いほど出現する可能性が高くなり, 本実験の試
片でも試料番号 $\mathrm{S} 2$ より $\mathrm{S} 3, \mathrm{~S} 3$ より $\mathrm{S} 4$ に大さな晶出け い素の存在が認められている。従つて, 本試片中のけい 素の存在形態としては固溶けい素, 析出けい素, 晶出け い素の 3 種類を考慮しなければならない。

\section{$4.2 \mathrm{Al}-\mathrm{Si}$ 合金中の固溶けい素}

本実験で用いた試料中のけい素の存在形態は固溶けい 素, 析出けい素と偏析によつて生じた晶出けい素の 3 種 類があることを $4.1 て ゙$ 考察した。そこで，この 3 種類の 内，固溶けい素について考察する。

3.2 より, 比抵抗値 $\rho$ におよぼすけい素添加量の寄与 率は(1)式より

$$
\partial \rho / \partial[\mathrm{Si}]=0.24(\mu \Omega \cdot \mathrm{cm} / \mathrm{wt} \%)
$$

となる。

一般に希薄合金（この場合 $\mathrm{Al}-\mathrm{Si}$ 合金）の比抵抗は次 式で表される。

$$
\rho=\rho_{0}(T)+\rho(\mathrm{Si})+\Delta(T, \mathrm{Si})
$$

ただし，

$\rho_{0}(T)$ : フォノンによる電子散乱に起因する項であ り，温度のみに依存する。 $(\mu \Omega \cdot \mathrm{cm})$

$\rho(\mathrm{Si})$ : 残留抵抗であり, 温度には依存せず母地中 の溶質原子濃度（この場合けい素の原子濃 度）に依存する。 $(\mu \Omega \cdot \mathrm{cm})$

$\Delta(T, \mathrm{Si})$ : マチーセン則からのずれで温度と母地中の 溶質原子濃度(この場合けい素の原子濃度) に依存する。 $(\mu \Omega \cdot \mathrm{cm})$

$\mathrm{Al}-\mathrm{Si}$ 合金における $\Delta(T, \mathrm{Si})$ の值は小さい7)ので無視 できる。本実験の場合，(5)式より

$$
\partial \rho / \partial[\mathrm{Si}]=\partial \rho(\mathrm{Si}) / \partial[\mathrm{Si}]
$$

となり，室温下での $\mathrm{Al}-\mathrm{Si}$ 合金の固溶けい素量は $\mathrm{Al}-\mathrm{Si}$ 合金中のけい素添加量に比例し，その寄与率はほぼ(4) 式の $0.24 \mu \Omega \cdot \mathrm{cm} / \%$ 程度の值を示す。この值は比抵抗増 加の測定值 $0.63 \sim 1.72 \mu \Omega \cdot \mathrm{cm} / \mathrm{wt}^{8} \%^{8)}$ よりも小さいが, 少なくとも試料番号 $\mathrm{S} 1$ ～S4 になるに従い固溶けい素の 量は $\mathrm{Ai}-\mathrm{Si}$ 合金中のけい素添加量に比例して増加してい ることを示している。

この固溶けい素の増加は原子レベルでのアノード分極 抵抗の低下をもたらすと考えられるが，3.1の腐食後の 表面観察でアルミニウム地は滑らかなこと，また 3.5 の アノード分極曲線においてその形や孔食電位がほとんど 変らないことなどを考慮すると，この固溶けい素が $\mathrm{Al}-$ $\mathrm{Si}$ 合金の腐食減量におよぽす影響は非常に小さいもの と考えられる。従つて，本実験における Al-Si 合金の腐 食におよぼす影響としては，析出けい素と晶出けい素の 2 つに絞るのが妥当と思われる。

\section{$4.3 \mathrm{Al}-\mathrm{Si}$ 合金の腐食量と分極曲線}

試料番号 S1 から S4 の腐食量とそれらの分極曲線の 関係を，Fig. 10 の分極曲線を使つて定性的に考察す 


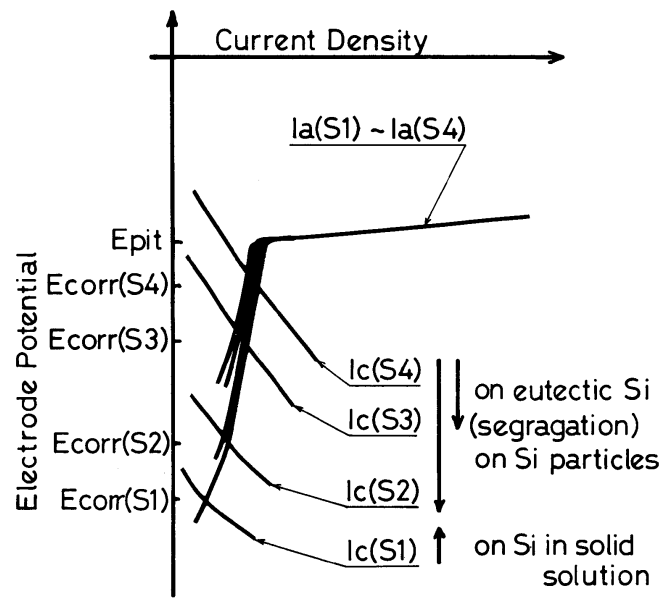

Fig. 10 Schematic explanation of polarization curves for $\mathrm{Al}-\mathrm{Si}$ alloys in $0.1 \mathrm{M} \mathrm{NaCl}$ solution.

る。

アノード分極曲線については，浸漬直後も浸漬 600 時 間後も試料番号 $\mathrm{S} 1 \sim \mathrm{S} 4$ ともそれらの孔食電位は -0.6 $\mathrm{V}$ と一定值を示した結果から, $\mathrm{Al}-\mathrm{Si}$ 合金の腐食過程に おいてアノード分極曲線の形はほとんど変化しないもの として取り扱らことができる*****。

カソード分極曲線については, 経時変化が認められ る。特に, けい素添加量の多い試料番号 S3, S4 のカン 一ド分極抵抗は著しく小さくなる。このカソード反応は 水の還元反応である。水素の交換電流密度はアルミニウ ム表面上で $10^{-8} \mathrm{~A} / \mathrm{cm}^{2}$, けい素表面上で $10^{-6} \sim 10^{-8} \mathrm{~A} /$

***** Fig. 6 の実際のアノード分極曲線で全面溶解域 は現れないのに，Fig. 10 の模式図で全面溶解 域が存在する理由は，(3)式の関係が成立する 限り, $\mathrm{Al}-\mathrm{Si}$ 合金の全面溶解域は存在すると考 えることができることによる。この全面溶解 域は非常に狭いものと考えられ，この全面溶 解域の存在は Fig. 1 や Fig. 8 の SEM 観察から も首肯できるものと思われる。 $\mathrm{cm}^{2}$ 程度であり ${ }^{9)}$, けい素添加量の多い試料番号 $\mathrm{S} 3, \mathrm{~S} 4$ で，水の還元反応はより起こりやすくなる。また，その 反応はアルミニウム母地よりけい素含有率の高い析出け い素, 晶出けい素表面上で起こりやすかつたものと考兄 られる。カソード面積の大小から, 本試片上で起こつた カソード反応は，析出けい素よりむしろ晶出けい素表面 上で最も起こりやすい。これらのことはFig. 7 の試料 番号 S3 S 4 のカソード分極曲線の経時変化や Fig. 9 のカソード電流の経緯曲線が試料番号 S1 S $\mathrm{S} 2$ のそれ らと比較して特異的であることの説明の一助になるもの と思われる。

\section{5. 結 言}

$0.1 \mathrm{M} \mathrm{NaCl}$ 水溶液中の $\mathrm{Al}-\mathrm{Si}$ 合金の腐食特性や電気 化学的性質を調べた結果，次の結論を得た。

(1) $\mathrm{Al}-\mathrm{Si}$ 合金中のけい素添加量が増えるに従いその 腐食量は増加する。 $\mathrm{Al}-\mathrm{Si}$ 合金の腐食はカソード反 応支配である。

(2) $\mathrm{Al}-\mathrm{Si}$ 合金の腐食のカソード反応は水の還元反応 であり，その反応はけい素添加量が多く面積の広い 晶出けい素表面上で起こりやすいと考えられる。

終わりに，本試験の供試材を提供して頂いた三菱アル ミニウム(株技術研究所の当摩建氏に感謝の意を表しま す。

本研究の一部は軽金属奖学会の補助金によつたことを 記し，謝意を表します。

\section{参 考 文 献}

1）アルミニウム加工技術便覧編集委員会編：アルミニ ウム加工技術便覧，日刊工業新聞社（1970）.

2）軽金属学会：アルミニウムの表面処理技術（1981）.

3) L. F. Mondolfo: Aluminum alloys, Butterworths (1979).

4) 世利, 田頭：軽金属投稿中

5）長村，中村：軽金属，33 (1983), 55.

6）大日方，小松：日本金属学会，19（1955), 736.

7) Y. Fukai: Phys, Rev., 186 (1968), 697.

8）横田，佐藤：軽金属，32 (1982)，432.

9）喜多，魚崎：電気化学の基礎，技報堂（1983）。 